\title{
OCCURRENCE OF CLOSTRIDIUM PERFRINGENS IN SOME MEAT PRODUCTS IN SHARKIA AND KALYOBIA GOVERNORATES
}

\author{
Fatein, S. H."; El-Taher, E. M.** and Hemmat M. Mrahlm* \\ - Faculty of Veterinary Medicine, Moshtohour, Zagazig University \\ " Foorl Hygiene and Control Deparment, Animal Health Research Instilule
}

\begin{abstract}
This study was conducted on 90 random samples of meat prodicts (30 exth of minced meat, berefburger and sausage. The cxumised samples were collected from diff ferent supermarkets at Sharkia and Kalyobia Governorates, and then subjected to bar. teriological investigation for isolation and identification of Clostridium perfingens. The

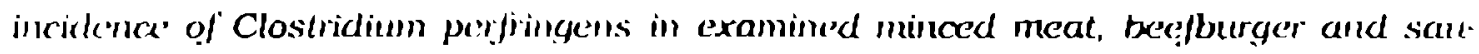
sage' luas 26.67\%; $16.67 \%$ and $40 \%$ respectively. from which 13.33\%. I0\% and 23.33\% werc Lecithinase positive strnins. The isolated strains were typed into tupes $A$, B. D and $C$ in 8.89\%, 3.33\%; $2.22 \%$ and 1.11 \%. respectively. All isolated Clostridium perfringens type A strains resist heating at $100, C$ for 60 inintles, while $87.5 \%$ resist for 120 minutes, meanwhile 62.5\% resist for 150 inimute and finally 37.5\% resist for 180 minules.
\end{abstract}

The importance of Clostridium peifringerns and its effect on the public health as uvell as the scientific base which must be adopted in meat products industry ues also discussed.

\section{INTRODUCTION}

Meat products proved to be available allover the world especially ready-lo-cal types liable to harbour dillerent lypes of microorganisins, among these microorganisms toxigcric anacrobes as Clustridium perfingens which is ublquitous in nature usually detected in dust, soll foucl. intest1nal contests of man, antmals and work surfaces (Barl et al., 1992 and Hayes, 1992).

Ciostriclium perfrngens spore may contaminate meat at abattoir level, during transunission as well as markcling level, whlle meat product contamination may oecur during processing at cattcring estal,isiluments and durlug home preparation (Poxton et al., 1989). Clustridlum perfring- 
Fatein, S. H. et al...

ans strains may eausc a number ol human dlseases ranging from neciotic enterylis in wound inlections and like tlureaten gas gangrene (Norris and Pettlpher, 1987) and (hey are divided into five toxirologlcal types on the basis of lleir toxins produetion (Smlth, 1979 and MeDonel. 1980).

Clustridium perfringens type $A$ is responsible for food poisoning diseases as prevlously recordcd by (Tortora and Zebral, 1988, Hewitt et al., 1989 and Hayes, 1992).

Clostrldit... perlingens type $A$ strain produce crterotoxin which have markedly heat resistant spores anc most frequently eucounlered with food poisoning. The ingesting of meal rontanilnated with Clostridlum perfringens strains is considered to be unlit lor human consmuptton and fead to look poisonlng as previously mcnlloncd by Tortora and Zebral (1988): Hewitt et al. (1988); Poxton et al. (1989) and Hayes (1992).

Clostriclium perfringens strahns were isolated from meat and meat ploducls simules which ladl Ixe:u invesligaled by El-Naenacey (1989): Itman et al. (1989); Guzman et al. (1990) and Hassan (1994). liurthermorc Clostrldhim periringens strains were isolaled fion ready-lo-cat neat products (mined meat, becluurger, sausage. luncheon cle) with different moldenecs as previously recordecl by El-Hosselny (1987; El-Naenaeey 91989): Guzman et al., 1990): Edris et al. (1992): Hassan (1994); El-Lawendy (1996) and Hassan (1999).

Closutillum perfringens might lind lhedr way into meat and meat products cilher clirectly fiom the slathlitered anlmals or by subseguent contambalion from the hands of cookets. bulchers and oller meat handlers In slaughterhouses, meal markets and retail shops as previously menlloned by Gotz (1976) and Mllev (1976).

Clostriclium perfringens strains were sutvlved licaling at $100^{\circ} \mathrm{C}$ (Botllng or steamings) for vari-

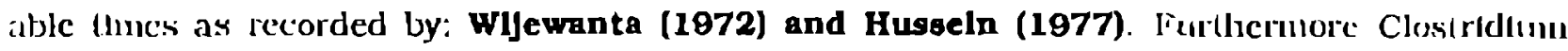
رerfringens lype A stralns were llsc nost frequent lieal resistant strains as recorded by ElBardisy (1984), El-Nacnacey (1989), Hassan (1994); EI-Lawendy (1996) and Hassan [1999).

'Thereliare the main purpuse of the current study is in liwestlgate the previlence of Clostridt-

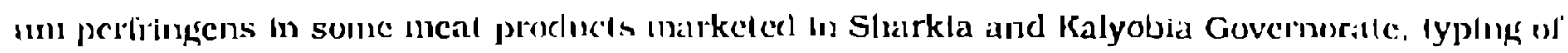
ille isolates and the ellect of heat on the Clostzidluni perfringens isolates and throw light on the required salnilary measures whtch mintmize the posstble hazards during consumption of such meal products whieh had becn contammated with these Loxigenic strains.

\section{MATERIALS AND METHODS}

A total ol !n saniples of differcul meal products represented by mineed meil. becllounger and 
Fatein, S. H. et al...

sausage (30 of each) were colleved randomly from supermarkets in Sharkia and Lialyobia Governorales. Sumples were transferred to the laboratory in iec box and kept in relial parekasges under complete aseptic condiljons wilhout unduc delay for bactcriological examination

Clostricliun perfringens comnt was assayed according to the tecbnicun adopted by ICMSF (1978) using cooked meat bruth lulscs incubated anacrolsteally for 24 hours at $37^{\circ} \mathrm{C}$ followed by subculturu!s onto Nenmycin Blood Agar plates which were íncubated also anderobically all $37^{\prime \prime} \mathrm{C}$ lor 48 hour, Suspected colonies ol Clostridlum Perfingens werc lested for lecithinase activily by using Figg Yolk Agar plates (Nagler's rcaction). Furthermore Isolated strains were lyped by intradenal inoculation test in Gina piffi. Ilowever, the heat resistant test of Clostriclinu perfiningans spores was carried out at $100^{\circ} \mathrm{C}$ lor GO. 120, 150 and 180 minutcs aremding fo Hussein (1977).

\section{RESULTS \& DISCUSSION}

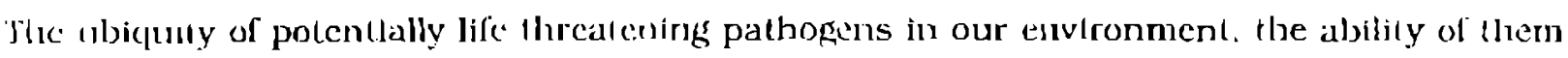
lo surviwe or proliferate in redired oxysen ilruosphere and under refrigeration as well as its presence 111 how number is necessiny for diseasc procluction, which indicales lhe scriousness and pulcutial lazalds (Ganowiak, 1986).

Table (1) illustrated that the sausigge samples were more highly contaninaled with Clostridi-

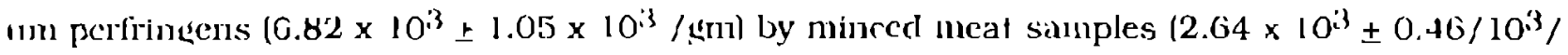
ginr) while llte beelburger samples were leasl contaminated $\left(9.27 \times 10^{2} \pm 2.12 \times 10^{2} /\right.$ sint $^{2}$ ) At the

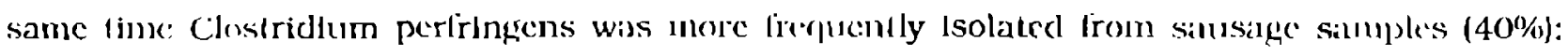
followed by minced uncal samples (26.67\%) and beefunger samples (16.67\%). Moreover, among the isolatcl Clostridium perifingens stralns fron minced meat. becfburger and sausage samples $13.33 \%$. $10 \%$ and $23.33 \%$ were lecilhinase positlve. respectively. In this work, lac incidence of Clostridium perfringens in sausabe samples was lower than results which previously repolted by El-Naenaeey (1989); Guzman et al. (1990) and El-Lawendy (1996). where Clostridiun perlingens was isoluted from the exantined sanusage samples in $62.7 \%, 78.9 \%, 80.8 \%$ and $62 \%$, respeclively. On the other hand lower incidence wils recorded by Yougsef (1984) $25 \%$ El-Kelish et al. (1987) $20 \%$ and Hassan (1999) $25 \%$. In the current study Clostrldium perfringens was isolated liom $40 \%$ of inineed meat samples. This results seems to be agree with those iccorderl by Ei-Nacinecy (1999) 40\% and Hassan (1999) and oppositely higher findings were recorded by Youssef (1984) $77.1 \%$

Regardins to beefluturger samples. Clostridium perfringens was isolated in $16.67 \%$. His resull agree well wilh those reported by Hassan (1999) $15 \%$, while higher incidenec was recorded by 


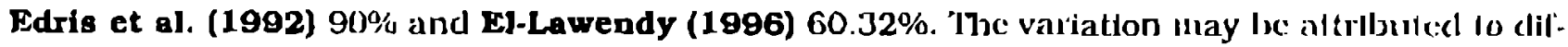

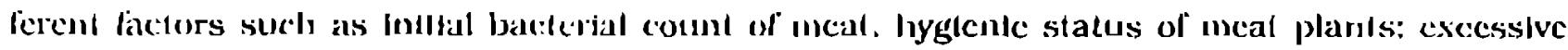
landling eluvlng proc cssing and addition of conlaminatcd splecs.

Regareling the results recorded in (able (2) Iyplng of 14 strains of Lectumase posillve Clostrlal-

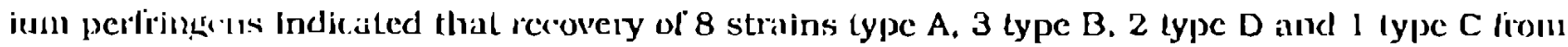
the examinert intneed meat procluct samples. Accurately. type A was detected fiom 16.67\% salusige samples. 6.67\% from mineed meal samples and $3.33 \%$ from beelburger samples, ivhile type $B$ was recorded in 6.67\% and 3.33\% each of beclburget and minced meal samples respec:lirely.

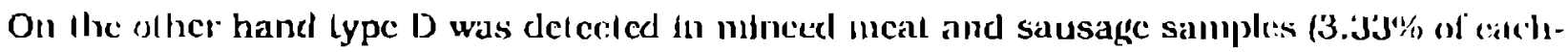
0. whereas ly pe $\mathrm{C}$ was only recovered from $3.33 \%$ of the examlned sausage sanlyples. This linclings nearly similar to those recorcled by El-Naenaeey (1989); Hasoan (1994); El-Lawendy (1996): Miwa et al. (1998) and Hassan (1998).

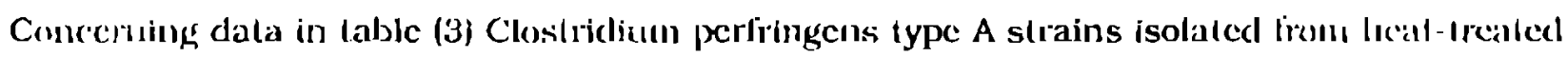
sausilfe samples were resistant in cooking Iemperalure for 180 minules at $100^{\circ} \mathrm{C}$ mallice 1 lian beciburacr samples (tll 120 minutes). Moreover isolates fiom nunced neal was resistanl for 150 minu(cs. Nearly smilar results werc oblainced by El-Neenacey (1989) and Hassan (1999). In this targel Smith (1979) recorded that Clostridum perfilngens lype A strains can survire cooking and has the ability to produce heal resistanl spores. Whercas Robers and Dernck (1978) reported llat spores of classical st lains which responsible for human tllness other llian liord poisonlng ivere more schistuve to heal han spores of lood polsoning one. Hence there are apparent

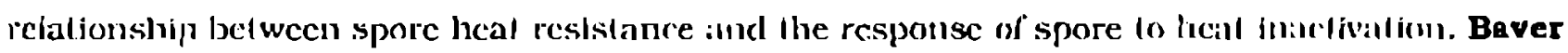
ct al. (1981) declared that spores of Clostridlun perlingens surviving cooklng or resilling from jost-processing contamtnation nust multiply untJl sumejenl numbers were developed lo curlsc Illness. and this may :lltributed to fenctle dillerences among Clostridium perlingens stralus re:gardlns to the heat resistance of (heir spores (Doyle, 1989).

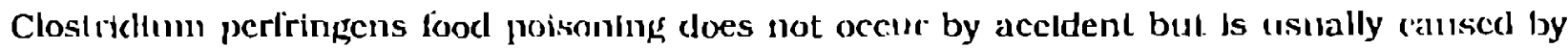
innorance. which leads to mistakes in lood handling. Meat hygicne covers all aspects of process-

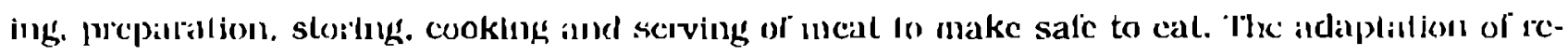
rent quility assurance programs such as Hazard AnalysIs Critjcal Conlrol System (IIACCl'S) and good matmuliacluring Practlecs (GMPs) are requircd to consurc lood salety. 
Fatein, S. H, et al...

Table (1) : Incidence ol Clostridium períingens isolated from the examined meat product samples $(n=30)$

\begin{tabular}{|c|c|c|c|c|c|c|c|}
\hline \multirow{2}{*}{$\begin{array}{l}\text { Meat } \\
\text { product }\end{array}$} & \multicolumn{2}{|c|}{$\begin{array}{l}\text { Positive } \\
\text { samples }\end{array}$} & \multicolumn{2}{|c|}{$\begin{array}{c}\text { Lecithinase } \\
\text { positive }\end{array}$} & \multirow[t]{2}{*}{ Max. } & \multirow[t]{2}{*}{ Min. } & \multirow[t]{2}{*}{ Mean $\pm S . E}$. \\
\hline & No. & $\%$ & No. & $\%$ & & & \\
\hline Minced meat & 8 & 26.67 & 4 & 13.33 & $6.40 \times 10^{3}$ & $8.70 \times 10^{2}$ & $2.64 \times 10^{3} \pm 0.46 \times 10^{3}$ \\
\hline Beefburger & 5 & 16.67 & 3 & 10.00 & $1.04 \times 10^{3}$ & $5.90 \times 10^{2}$ & $927 \times 10^{2} \pm 2.12 \times 10^{2}$ \\
\hline Sausage & 12 & 40.0 & 7 & 23.33 & $2.10 \times 10^{4}$ & $1.26 \times 10^{3}$ & $6.82 \times 10^{3} \pm 1.05 \times 10^{3}$ \\
\hline
\end{tabular}

Table (2): Typing of Lecihinase posilive strains of Clostridium pertringens in the examined meal products samples $(n=30)$.

\begin{tabular}{|c|c|c|c|c|c|c|c|c|c|c|}
\hline \multirow{2}{*}{$\underbrace{\text { Toxin }}_{\text {Meat }}$} & \multicolumn{2}{|c|}{ A } & \multicolumn{2}{|c|}{8} & \multicolumn{2}{|c|}{ c } & \multicolumn{2}{|c|}{ D } & \multicolumn{2}{|c|}{ Total } \\
\hline & No. & $\%$ & No. & $\%$ & No. & $\%$ & No. & $\%$ & No. & $\%$ \\
\hline Minef $\cdots$. If & 2 & 6.67 & 1 & 3.33 & - & - & 1 & 3.33 & 4 & 13.33 \\
\hline Beelbut, & 1 & 3.33 & 2 & 6.67 & - & - & - & - & 3 & 10.00 \\
\hline Sausidge & 5 & 16.67 & - & - & 1 & 3.33 & 1 & 3.33 & 7 & 23.33 \\
\hline Tola! & 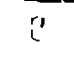 & 8.89 & 3 & 3.33 & 1 & 1.11 & 2 & 2.22 & 14 & 15.56 \\
\hline
\end{tabular}

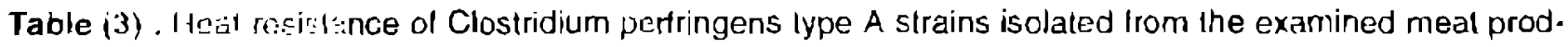
ucal simpless.

\begin{tabular}{|c|c|c|c|c|c|c|c|c|c|}
\hline \multirow{3}{*}{ Produr: } & \multirow{3}{*}{$\begin{array}{c}\text { Type } \\
\text { of strains }\end{array}$} & \multicolumn{8}{|c|}{ Resistance Time } \\
\hline & & \multicolumn{2}{|c|}{60 minutes } & \multicolumn{2}{|c|}{120 minutes } & \multicolumn{2}{|c|}{150 minutes } & \multicolumn{2}{|c|}{180 minute } \\
\hline & & No. & $\%$ & No. & $\%$ & No. & $\%$ & No. & $\%$ \\
\hline Minceral ileal & 2 & 2 & 100 & 1 & 50 & 1 & 50 & - & - \\
\hline Deefburijor & 1 & 1 & 100 & 1 & 50 & - & - & - & - \\
\hline Sausagra & 5 & 5 & 100 & 5 & 100 & 4 & 80 & 3 & 60 \\
\hline Tolal & 8 & 8 & 100 & 7 & 87.5 & 5 & 62.5 & 3 & 37.5 \\
\hline
\end{tabular}


Fatein, S. H. et al...

\section{REFERENCES}

Barl, A.: Amar, M. Y.: Slddlqui, S. A and Aslf, M. (1992) : Anaerobic and acrolsic cnterolox!fienir bacterla in ready-lo-eat loods in Pakistan. Proceeding of Brol Worlel Congress lickdborne Infection and Intoxication. Berlin. Germany.

Baver, F. T.: carpenter, J. A. and Reagan, J. D. (1981) : Prevalence of Clostridium perlitangens in jenk during processing. J. Food Prolcc. 44 (4): 279-283.

Doyle. M. D. (1989) : Foodborne Bar(crial pathogcns. Pp. 193-231. Mared Dekker. Inc. Ncw York and Basal.

Edris. A. M.; El-Bardisy, M. and Mousa, M. M. (1992) : Studies on microbial slatus on some marketed meat producis with speelal relercnce to C. periringens. Egypt. J. Apy) S Sc:., 7 (12): 19-30.

El-Bardisy. M. M. M. (1984) : Bactcriological studles C. pertringens on to meat. M.V.Se. Thiesls (Microbiology) Fae. Vet. Mcd. Cairo University.

El-Hosseiny. M. M. (1987) : Bactriologlcal studies on meat and mcat produets. I'h.D. Thesis (Microbioloky]. Far. Vet. Med. Cairo University.

El-Kelish, H.: Morrshdy, A; El-Atabany, A. and Hafez, A (1987) : C. perfringens In liteshli sallsiggc marketed in Zaggazig city. Zaggazig Vet. J. (1) : 159-165.

El-Lawendy, H. M. T. (1996) : Occuitence of C. perlirngens in loeally produced mcit products. M.V.Sc. Thesis (Mcat Hyglene) Fac. Vet. Med.. Moshtohour Benha Branch. Zagaizig̣ Universily.

El-Naenaeey, E. Y. M. (1989) : Occurrence ol C. perfirlngens type A. Ph. D. 'Thesis (Microbiology) fac. Vet. Zagazlg University.

Ganowlak. Z. (1986) : Objectives of Irivestigations of foodboinc disease outbrcaks. Pruceclings of the 3rd Congress. Foodbornc Inlectlon and intoxication Berlin. Germany.

Gotz, J. (1976) : The presence of C. perfringens in bovine, broilers and possible cordimination durings slaugh lering. Heiscliwirlschaft.. 56 ('2): 231-235.

Guzman, A. M. S. de: Mlealizzi, B.; Pagano, C. E. T. and Gimenez, D. F. (1990) : Incidence of C. perlilngens In fresh sausage in Argentlna. J. Food Protec. 53 92): 173-175.

Hassan, M. A. (1994) : Incldence and scrolyping of C. periringens among onimals slaughtered al Citiro and Giza abattoirs. M. V.Sc. Thesis (Meat Hygiene) Fac. Vet. Med. Moshitolonr. Bcolli.l Branch. zagazig University. 
Fatein, S. H. et al...

Hassan, M. A. (1999) : follow up of senuc patlogens in meat preducts anid then resistance to cellain preservatives. Beni-Suel vet. Med. J. 9 (3):.417-429. . :

Hayes, P. R. (1992) : Food Microbnology and Hygienc. 2nd Ed Elcscvir Applled Scienre London Now York.

Hewitt, J. H.; Begg, H.; Hewish, J.; Rawaf, S.: Stringer, M. M. and Theodore, G. B. (1989) : Litile outbreaks of $\mathrm{C}$. perfingens lood poisoning associater with the consumption of boil. 、 salmon. J. of Flyblene. 9791 ): 7 1-80.

Husseln, A. Z. (1977) : The physical condiltons of cattle before slaughtering and ils tclitionslip (1) probable isolatkon of C. perlingens fiom calreasses. Kande at nalyk. Vilronsih AgriculI wre listitutc, USSR.

International Commission on Microbiologlcal specification for Foods "ICMSF" (1978) : Microorganisnus In Foods. Their Significanec and Methods of Enumeralion 2nd ed. Univ. of Turonlu Press. 'Toronto. 13ullalo. London.

Itman, R. H.: Ikbol Farrag; Arab. F. M. A. and Makhareta, M. A. M. (1989) : $\Lambda$ prelimflary inrestlgation on some anacrobie bacterla in the llver of buftaloes and cannels. Vel. J. Giza. 37 (3): 489-500.

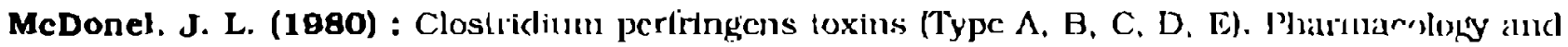
Therapoutics. 10:617-655.

Mulev, M. (1976) : Normal status af Baellus cereus and C. perlingens in the body of normal animbls (rattle. shecp and sivine). Vorogcnizma Velerinaremeditisinki Nanki. 13 (4): 53$5 \%$

Mlwa, N.; Nishina, T.: Kubo, S.; Atsuml, M. and Honda, H. (1998) : Amount of cnlerotoxigicnic Clostridium perfringens in meal cletected by nested PCR. J. rood Microbiol., 43 (J): 195-200.

Norris, J. R. and Pettlpher, G. L. (1987) : Essays in Agriculture and livod Micrubiolog'y. Jolu Wilcy and Sons Chiehesler. New York, BrIsbane. Toronto.

Poxton, L.; Brown, R.; Fraser, A. G. and Colle, J. G. (1989) : Enteropathogenic Clustriclia and Clastricliun botulinum. Praelical Medleal Mlcrobiologsy. 13/h Editton Churchill Livlngslone London and Nerv York.

Roberts. T. A. and Derrick, C. (1978) : Cited after Doyle (1989). Smith. L. D. S. (1979) : Virulence factors of Clostridiun perfringens. Revicw of Infectious Discases. 1: 254-262.

Tortora, J, D. de O. and Zebral, A. A. (1988) : A human food polsoning outbrenk in liodle Ja- 
Fatein, S. H. et al...

116

Meiro caused by sausage contamlnated with enterotoxigenic Closhtrlium perfitingens Iypce A. Ruista de Microblelogla. 19 (2): 133-1 18 CBA.

Wijewanta. E. A. (1972) : Isolation of heat resistant Clostridium perfringens from licall hy caltle. Comell Veterinarian, 62 (1): 26-31.

Youssef, H. (1984) : Incidence of Clustridium perlirlngeris in meat products in Assull cily. Assiul VCl. Mcd. J. 12 923): 145-147. 
Fatein, S. H. et al...

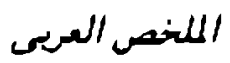

مدى تواجد الكلوستريديم برفرنجينز فى بعض منتجات اللحوم بمحافظتى الثرقية والقليويية

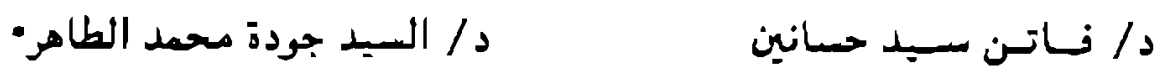

$$
\begin{aligned}
& \text { / / همت مصطنى إبراهيم }
\end{aligned}
$$

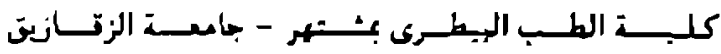

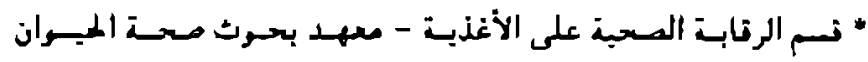

أجريت الدراسة على عدد تسعون عينة عشوائية من منتجات اللحوم ( r عينة من كل من اللحم المفروم وائبيف بيرجر

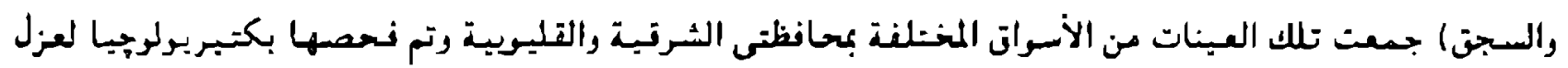

$$
\text { وتصنيف ميكروب الكلوستريديم برنرنجيتر. }
$$

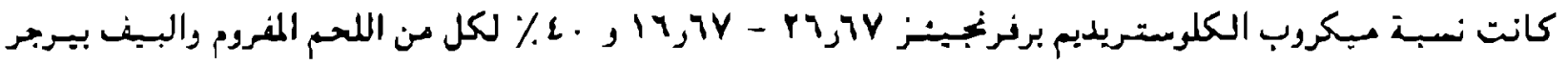

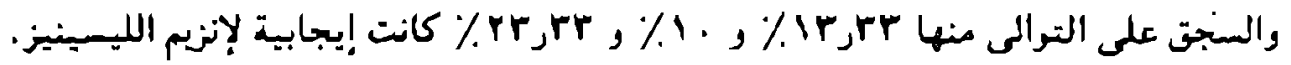

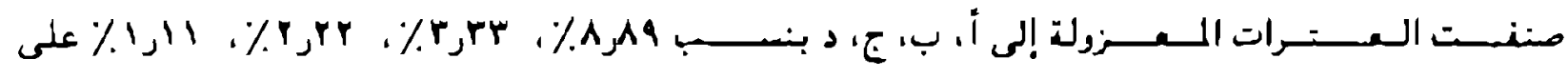
الترالى. - n

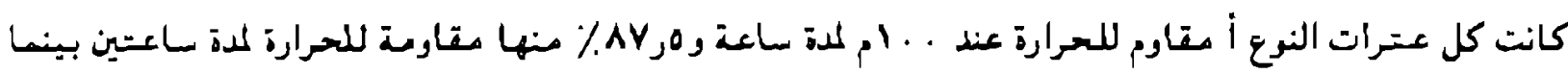

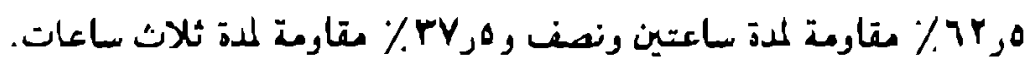
كسا نوتشت أهية تلك الميكروبات وتأثيره على الصحة العامة وكذلك الترهيات الواجب إتباعها نى مصانع منتجات

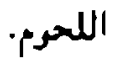

